Article

\title{
Automated SEM-EDS Analysis of Transition Metals and Other Metallic Compounds Emitted from Incinerating Agricultural Waste Plastic Film
}

\author{
Tae-Han Kim ${ }^{1}{ }^{\mathbb{D}}$, Boo-Hun Choi ${ }^{2}$, Choong-Sik Yoon ${ }^{3}$, Yong-Kyu Ko ${ }^{4}$, Moon-Sung Kang ${ }^{5}$ \\ and Joongjin Kook ${ }^{6, *(1)}$
}

check for

updates

Citation: Kim, T.-H.; Choi, B.-H.; Yoon, C.-S.; Ko, Y.-K.; Kang, M.-S.; Kook, J. Automated SEM-EDS Analysis of Transition Metals and Other Metallic Compounds Emitted from Incinerating Agricultural Waste Plastic Film. Atmosphere 2022, 13, 260. https://doi.org/10.3390/ atmos 13020260

Academic Editor: Paola Fermo

Received: 3 December 2021

Accepted: 1 February 2022

Published: 3 February 2022

Publisher's Note: MDPI stays neutral with regard to jurisdictional claims in published maps and institutional affiliations.

Copyright: () 2022 by the authors Licensee MDPI, Basel, Switzerland. This article is an open access article distributed under the terms and conditions of the Creative Commons Attribution (CC BY) license (https:/ / creativecommons.org/licenses/by/ $4.0 /)$.
1 Department of Green Smart City, Sangmyung University, 31 Sangmyungdae-gil, Dongnam-gu, Cheonan-si 31066, Korea; taehankim@smu.ac.kr

2 Department of Environmental Resources, Graduate School, Sangmyung University, 31 Sangmyungdae-gil, Dongnam-gu, Cheonan-si 31066, Korea; 2020d3005@sangmyung.kr

3 PKoLAB, 314 Techno 2-ro, Yuseong-gu, Daejeon 34131, Korea; james@pkolab.com

4 COXEM Co., Ltd., 199 Techno 2-ro, Yuseong-gu, Daejeon 34131, Korea; kyk@coxem.com

5 Department of Green Chemical Engineering, Sangmyung University, 31 Sangmyungdae-gil, Dongnam-gu, Cheonan-si 31066, Korea; solar@smu.ac.kr

6 Department of Information Security Engineering, Sangmyung University, 31 Sangmyungdae-gil, Dongnam-gu, Cheonan-si 31066, Korea

* Correspondence: kook@smu.ac.kr

\begin{abstract}
Illegal open burning, which is criticized as a leading source of air pollutants among agricultural activities, currently requires constant effort and attention from countries around the world. A speciation analysis method is required to examine the harmful effects of particulate matter generated by incineration on the human body. In this study, to simulate open-air incineration, infrastructure for incineration tests complying with US EPA method 5G was built, and a large-area analysis was conducted on the particulate matter through automated SEM-EDS. For test specimens, waste mulching LDPE collected by Korea Environment Corporation Dangin Office was used. To raise the identifiability of analyzed particles, the specimen was sampled on a plate made of Ag, which has a high atomic number, three times. Metal particulate matter showed a high reaction to $\mathrm{C}$ and $\mathrm{C}-\mathrm{O}$. The ratio of metal particulate matters that reacted to $\mathrm{C}$ and $\mathrm{C}-\mathrm{O}$ was in the order of $\mathrm{Cu}(94.1 \%)>\mathrm{Fe}(83.3 \%)>\mathrm{Al}(79.7 \%)$. In this study, it was verified that waste mulching adsorbs metal chemicals originating from the soil due to its properties and deterioration, and that when it is incinerated, it emits particulate matter containing transition metals and other metals that contribute to excessive ROS production and reduction.
\end{abstract}

Keywords: PM (particulate matter); mulching LDPE; agricultural waste burning; incineration test; BES (back-scattered electron)

\section{Introduction}

Illegal open-air incineration, which is criticized as a leading source of air pollutants among agricultural activities, requires continuous efforts. Open-air incineration is a representative cause that has a major impact on the generation of fine dust in rural areas. In this regard, the government plans to make all-out efforts to prevent illegal incineration during the agricultural off-season through cooperation with agricultural groups and Korea Saemaul Center in the (2nd Fine Dust Seasonal Management System Implementation Plan (Proposal)) [1] in November 2020.

Agricultural wastes subject to open-air incineration are collected as statistics approved by Korea Environment Corporation under the Ministry of Environment (approval number 392005), and the statistical results are released annually in December of the following year 
in the form of the environmental statistics information of the resource circulation information system or in the periodicals (Agricultural Waste Survey). The Korea Environment Corporation has collected this information by dividing the agricultural waste into "the amount of agricultural waste film", "the amount of agricultural mulching waste film", "the amount of waste pesticide containers", and "the amount of collected/recycled agricultural waste film and pesticide containers." Among them, except for others with relatively small emissions, agricultural waste film can be classified by type into LDPE (low-density polyethylene) for greenhouses, LDPE for mulching, and HDPE (high-density polyethylene). Polyethylene (PE), a representative rubbery plastic, is the most widely used plastic with an output of about 80 million tons worldwide [2]. PE is supplied as LDPE and HDPE, and has different physical properties against deterioration and external impact. This is important in the life-cycle characteristics of the material and its ecological impact [3]. Pascall et al. confirmed that PE has high adsorption capacity by accelerating the movement of organic compounds due to its large volume, flexibility and mobility [4]. Microplastic (MP) such as PE can more effectively absorb metal ions through degradation than unused plastics [5]. Changes in homeostasis caused by $\mathrm{Zn}, \mathrm{Cu}$, and Fe are, reportedly, likely to cause retinal dysfunction, resulting in macular degeneration (AMD) with age [6-8]. Transition metals such as $\mathrm{Fe}, \mathrm{Cu}, \mathrm{Ni}$ and $\mathrm{Cr}$ can generate reactive oxygen species (ROS) and cause oxidative stress in biological tissues [9]. Metals such as $\mathrm{Zn}, \mathrm{Al}$ and $\mathrm{Pb}$ may also activate or decrease transition metals, thereby affecting their toxic effects [10].

Countries around the world have been conducting research on the emission of heavy metal substances in fine dust discharged from incineration, and it is reported that the smaller the particle size, the more heavy metals are concentrated [11,12]. A precise analysis method is required to examine the harmfulness of such particulate pollutants on the human body. Energy-dispersive X-ray spectroscopy (EDS) is a nondestructive method that can analyze particulate matter in elemental units, and does not require extraction or decomposition processes. Picuno et al. analyzed agricultural waste film collected from Huelva and Almeria in Spain through scanning electron microscope (SEM)-EDS with BSE (back-scattered electrons) applied, and found that it contains abundant chlorine derived from $\mathrm{KCl}$ and $\mathrm{NaCl}$, as well as single elements such as $\mathrm{Zn}$ and Fe or oxides [13]. A large-area analysis is effective for SEM-EDS analysis of the elements that have secured similarity to the complex particle composition of the specimen. The automated SEM-EDS specified in ASTM E1588 Standard practice among SEM-EDS analysis is a solution that facilitates analysis by tracking target elements scattered over a large area. The automated SEM-EDS enables automated morphological measurement and EDS data collection of unit particles through back-scattered electron imaging (BSEI) linked with EDS analysis [14], and provides fast screening even for samples composed of complex phase compositions [15]. It provides a limited morphological dataset in the quantitative chemical species analysis of conventional X-ray diffraction (XRD) or X-ray absorption spectroscopy (XAS), thereby facilitating the morphological analysis of target particles linked to the chemical dataset. It is used for particle composition analysis [16] such as Gunshot residue analysis (GSR) [17], waste incineration facilities [18] and volcanic ash analysis [19]. In addition, it is also widely used in relative content evaluation by the depth of concrete [20], alkaline silica reaction characterization [21], quantitative analysis of concrete porosity [22] and automated mineralogy $(\mathrm{AM})$ to optimize mineral concentration and metallurgical processes in the mining industry [23-27], etc.

In this study, infrastructure for incineration tests complying with US EPA method 5G was built in order to simulate open-air incineration, and a large-area analysis method on particulate pollutants from incineration of agricultural waste film through automated SEMEDS was proposed. We intended to present an analysis method that can simultaneously provide morphological and chemical datasets to analyze the environmental impact of open-air incineration after investigating the detection of major metal compounds derived from this. 


\section{Materials and Methods}

\subsection{Experiment Design}

A large number of vinyl byproducts are generated by agricultural work, which can be defined as agricultural waste film. As of 2019, the amount of agricultural waste film in Korea was 310,153 tons in total, with mulching LDPE the highest at 129,253 tons, followed by 106,298 tons of HDPE, 59,133 tons of LDPE for greenhouses, and 15,468 tons of others [28]. In this study, mulching LDPE, which has the highest amount of generation and for which the replacement time by the cultivation cycle is set, was selected as the incineration test sample. The test sample was provided with mulching LDPE collected by Korea Environment \& Resources Corporation Danjin office in Chungcheongnam-do.

In order to understand the origin of particulate pollutants identified through the incineration test results of agricultural waste film, it is necessary to identify additional artificial substances that can be synthesized in agricultural waste film and to verify their causality. In relation to the agricultural and livestock industries, materials that can be contained in the soil, in general, include fertilizers, pesticides, manure, and agricultural water, and rainfall may have an additional effect. Factors resulting from the natural environment, such as rainfall, precipitation, fine dust, and wind, have large regional variations as well as large differences depending on industrial facilities in a specific area. Therefore, more precise analysis requires comprehensive consideration with regional, geographic, environmental and industrial characteristics included.

Agricultural waste film used in this study was collected from Dangjin, Chungcheongnamdo, and the total area of Chungcheongnam-do is $8246 \mathrm{~km}^{2}$, which is $8.243 \%$ of the total area of Korea. Among this, the industrial complex area is $70.263 \mathrm{~km}^{2}$, and paddies and fields are $1457.85 \mathrm{~km}^{2}$ and $646.44 \mathrm{~km}^{2}$, respectively, accounting for $17.68 \%$ and $7.84 \%$. As of 2019, the amount of agricultural waste film in Chungcheongnam-do was 10,890 tons of LDPE for greenhouses, 8996 tons of LDPE for mulching, 17,508 tons of HDPE, and 928 tons of other (PVC, EVA, PO). Compared to other regions, LDPE for greenhouses, LDPE for mulching, and HDPE are evenly used, and they may be adsorbed to various components such as fertilizer, pesticides, and manure for crops by being buried in the soil. Agricultural waste films should be collected and recycled or discarded in a proper way, but some are incinerated in an illegal way [29].

The main crops in the Chungnam region include rice grains, wheat, mixed grains, beans, vegetables, special crops, fruit trees, greenhouse crops, and other crops. The area used for rice grains is $1321.74 \mathrm{~km}^{2}$ and is the largest area, followed by vegetables with $249.99 \mathrm{~km}^{2}$, and other crops with $142.15 \mathrm{~km}^{2}$. The types of fertilizers for crops include ammonium sulfate, urea, fused phosphate, potassium chloride, fused superphosphate, and composite fertilizer. The main ingredients of fertilizers are 33,696 tons of nitrogen, 13,070 tons of potassium, and 9128 tons of phosphate. Phosphate fertilizers and manure compost accumulate HMs such as cadmium (Cd) in the soil. Foreign substances such as plastics are likely to be mixed into food waste used in byproduct fertilizers (organic and fully fermented), indicating the possibility of microplastic getting into farmland. According to the fertilizer process standards, foreign substances such as plastic, metal, tile, vinyl, and tinfoil cannot be used as raw materials for fertilizer. However, as for food waste that can be used as a raw material for compost, mixed organic fertilizer and organic compound fertilizer, plus plastics such as food waste bags that are not separated in the collection and crushing steps, may be mixed.

The main ingredients of all pesticides used in Korea are fungicides (32.1\%), insecticides (28.3\%), herbicides (32\%), PGR (Plant Growth Regulator) 2.8\%, and others (4.9\%). Since there are no statistical data on consumption in the Chungnam region, the approximate consumption of each pesticide ingredients was calculated as a ratio to farmland in South Chungcheong Province. As of 2019, total pesticide consumption in Korea was $10.2 \mathrm{~kg} / \mathrm{ha}$ in 1,643,000 ha of total farmland. The farmland is in South Chungcheong Province is 210,428 ha, or $12.81 \%$ of the entire farmland, and its consumption of pesticides was 2146.37 tons. The ratios of fungicides, pesticides, herbicides, PGR, and others used 
in the production of pesticides are $32.1 \%, 28.3 \%, 32 \%, 2.8 \%$, and $4.9 \%$, respectively. So, it is inferred that 6687 tons of fungicides, 607 tons of insecticides, 687 tons of herbicides, 60 tons of PGR, and 105 tons others were used in Chungnam. The main ingredients of pesticides are divided into organophosphorus, carbamate, and organochlorine. Among them, residual pesticides that take more than 100 days for decomposition are bromacil, aldrin, dieldrin, heptachlor, BHC, Clotrane, DDT, etc. Overall, 11 domestic companies are found to manufacture copper compounds such as $\mathrm{Cu} 2(\mathrm{OH}) 3 \mathrm{Cl}, \mathrm{Cu}(\mathrm{OH}) 2, \mathrm{CuSO} 4$ and $\mathrm{Cu} 3 \mathrm{H} 2 \mathrm{O} 10 \mathrm{~S} 2$ as a fungicide for anthracnose and canker of major crops [30].

Based on the statistics in 2019, the total number of livestock was 291,996,000 heads and the amount of manure generated by them was $153,220 \mathrm{~m}^{3} /$ day. Of the generated manure, $122,319 \mathrm{~m}^{3}$ was self-treated and the remaining $30,901 \mathrm{~m}^{3}$ was consigned to others. Of the manure that is self-treated, $107,768 \mathrm{~m}^{3}$ was composted. The total number of livestock in Chungcheongnam-do is 30,317,771 heads, accounting for about $10.39 \%$ of the total number of livestock in Korea. As for the types of livestock, 347,214 cattle (275,157 Korean cattle, 18,346 beef cattle, 53,111 female dairy cattle), 1,442,931 pigs, 27,507,296 chickens (21,546,357 broiler chickens, 5,960,939 layer chickens), 329,446 ducks, 25,775 goats, 12,313 rabbits, 5748 deer, 65,469 dogs, 581,579 others were counted. When the amount of manure in the Chungnam region was calculated as the ratio of the number of livestock in the Chungnam region to the total number of livestock, the self-treatment amount was $12,709 \mathrm{~m}^{3} /$ day, the consignment treatment amount was $3211 \mathrm{~m}^{3} /$ day, and the amount of composting of the self-treatment was $11,197 \mathrm{~m}^{3} /$ day.

Comparing the heavy metal content by raw material of compost, pig manure compost has a much larger content of heavy metal than that of chicken manure or mixed compost in all items. In particular, in the cases of $\mathrm{Cd}, \mathrm{Cu}$, and $\mathrm{Ni}$, the contents in pig manure are significantly higher than that of chicken manure $(p$-value $<0.05)$. However, there were no items that exceeded the standards presented in the fertilizer process standards. As for mercury, it was detected only in trace amounts in the mixed specimen, but was not detected in most specimen. Pig manure compost contains a large amount of $\mathrm{Cu}$ along with $\mathrm{Zn}$, which is considered because PGR used for raising pigs has high content of $\mathrm{Cu}$ [31].

In order to collect complex information of the specimen, SEM-EDS, which applied SED (secondary electron detector) that analyzes the shape of the specimen surface, and BSED (back-scattered electron detector) that analyzes the composition of the specimen, were used. The conductive coating of the specimen for SEM-EDS analysis can protect the specimen from thermolesion and charging effects caused by incident electrons. However, the conductive coating may cause the deformation of the specimen depending on the coating material and thickness, the absorption of continuous $\mathrm{X}$-rays emitted, and the generation or the attenuation deviation of specific $X$-rays within the coating material. When carbon is analyzed, the conductive coating may be effective because of the less absorption of high-energy $\mathrm{X}$-rays, but when analyzing low-energy $\mathrm{X}$-rays ( $\mathrm{S} \mathrm{K} \alpha, \mathrm{O} K \alpha, \mathrm{F} \mathrm{K} \alpha$, etc.), the pretreatment may cause uncertainty in the analysis result [32]. Therefore, the conductive coating was excluded for a large-area and undeformed analysis of specimens with a large number of carbon particles and various metal compounds emitted by waste mulching-use LDPE incineration [33-37]. The samples excluding the coating were analyzed in a lowvacuum state in which charging does not occur, even for nonconductive samples, by setting the vacuum degree of the chamber to a pressure of 10-1 torr or more.

The threshold technique was applied to selectively analyze target particles during the analysis process. At this time, each particle depends on the BSE gray level. The emission energies of the elements of each particle were expressed in different gray levels, so the specimen was sampled on a plate made of $\mathrm{Ag}$, which has high atomic number, to raise the identifiability of the analyzed particles [38]. As for the number, size, and component of the incinerated specimens, a program called AztecFeature (version 5.0, Oxford instruments, High Wycombe, UK) with an automated image-processing solution, which integrated SEM images collecting BSE signals and EDS analysis, was used. Through a large-area analysis, ROS were generated, and transition metals that may cause oxidative stress in biological 
tissues and other metals that may affect toxicity by activating or reducing transition metals were extracted. For the identified target metal, the weight ratio of each particle was analyzed through a separate SEM-EDS to confirm the detection of a compound containing the metal.

\subsection{Incineration Test Infrastructure}

In this study, EPA Method 5G [39] was applied to create an open-air incineration environment for agricultural waste at the laboratory level. Method 5G specifies the duct connecting the incinerator and the external exhaust and the separation distance between velocity traverse port and sampling port in the duct. The duct is used with a diameter of 15.24 to $30.48 \mathrm{~cm}$, the velocity traverse port is at least $30.48 \mathrm{~cm}$ away from the incinerator to prevent turbulence, and the sampling ports are $10.16 \mathrm{~cm}$ or more away from the velocity traverse port. If the exhaust is connected to an elbow, it is required to keep the sampling port at least $2.54 \mathrm{~cm}$ from the elbow. Referring to the relevant standards, an experimental infrastructure for incineration of agricultural waste film was established as shown in Figure 1.

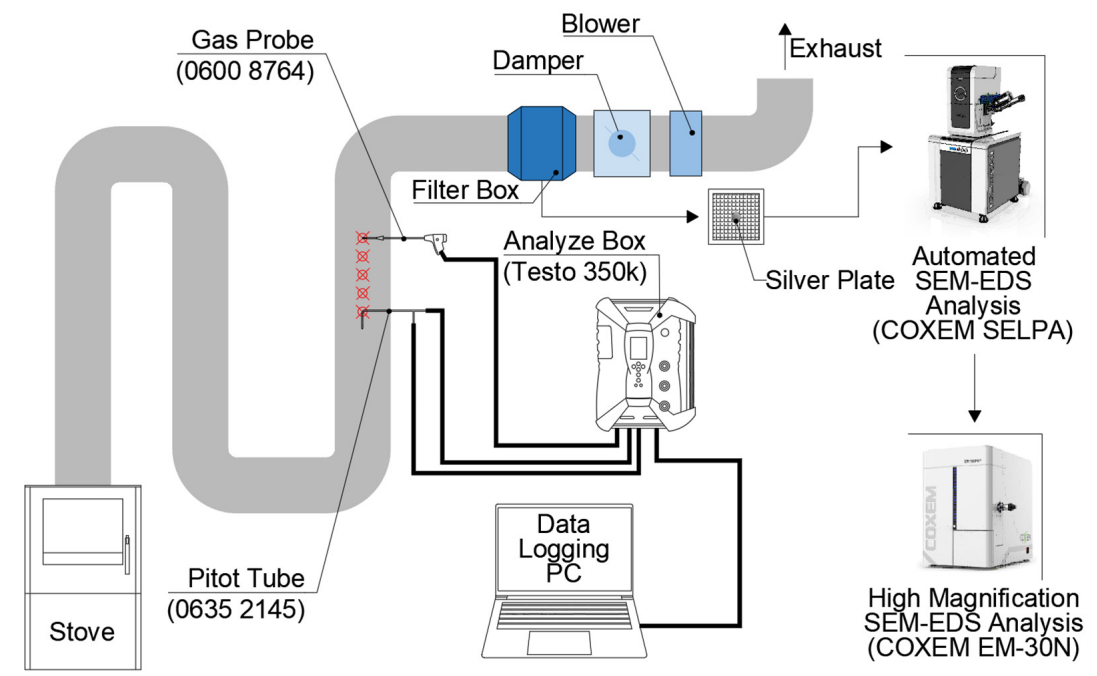

Figure 1. Diagram of test infrastructure for incineration experiment of waste mulching LDPE.

\subsection{Experimental Method}

Looking at the sample case of incineration of agricultural waste, among the previous studies on biological combustion for estimating the emission factor, the research on incineration of agricultural residues [40] collected a total of 15 samples in 5 repetitions, and the research on meat roasting [41] collected and analyzed 3 samples as in the relevant previous studies [42,43]. In this study, 3 samples in repetition were collected. The collected waste mulching LDPE specimens were cut off from the outside air, dried naturally in a room with a humidity of $60-70 \%$, weighed by $0.15 \mathrm{~kg}$ before the experiment, and were incinerated.

A Pitot tube (Testo 0635 2145, Testo Korea Ltd, Seoul, Korea) was inserted into the velocity traverse port and connected to an analyzer box (Testo 350k, Testo Korea Ltd, Seoul, Korea) to measure the wind speed by the differential pressure. In this infrastructure, the heat generated during combustion is naturally cooled through the duct, and the gas temperature of the velocity traverse port is set to be maintained at an average of less than $100{ }^{\circ} \mathrm{C}$. The particulate pollutants generated in the flame, mixed combustion stage and the soot stage, were collected from the duct [44]. Particulate matter sampling was conducted at a wind speed of $1.75 \pm 0.37 \mathrm{~m}^{3} / \mathrm{min}$. A plate made of $\mathrm{Ag}$ with a diameter of $47 \mathrm{~mm}$ (TAG0DS0008 Ag $47 \mathrm{~mm}$, Dia $\times 0.5 \mathrm{~mm}$ Th $4 \mathrm{~N}$ ) was used to minimize the interference in BSE analysis between soil components of agricultural waste film in the gas temperature range. The particulate matter collected on the plate was pretreated with a humidity of less than $35 \%$ and a temperature of $25 \pm 1{ }^{\circ} \mathrm{C}$ for more than $12 \mathrm{~h}$ using a desiccator. Characterization of particulate pollutants has been reported in the fields of air 
pollution caused by fine dust [45], climate change [46], and health [47]. In this study, the number of particles by diameter, chemical compounds, shapes by particle, and weight ratio were analyzed by applying the experimental method of previous studies. For this purpose, SEM (SELPA: Scanning Electron Microscope for Particle Analysis, COXEM, Daejeon, Korea) equipped with SSD-EDS (Xplore High throughput Silicon Drift EDS Detector, Oxford Instruments, High Wycombe, UK) capable of a large-area analysis was used, and AZtec (version 5.0, Oxford Instruments, High Wycombe, UK) were applied to automatically integrate and analyze the analysis.

It is necessary to calculate the acceleration voltage range in which particles with the smallest particle diameter are not interfered with by the interaction volume. Using Monte Carlo simulation, $15 \mathrm{kV}$ corresponding to a depth of $1 \mu \mathrm{m}$ was adopted (Figure 2). In order to secure the input count rates at the level of 13 to $19 \mathrm{k}$, WD (working distance) was set from 11 to $13 \mathrm{~mm}$, and an analysis time of $1 \mathrm{~s}$ was allocated for each particle to perform precise component analysis. The SEM-EDS analysis area was set to a range of $5 \times 5 \mathrm{~mm}$ in the center of the plate at $\times 200$ magnification, and the elements detected from the exclusion of the sum peak region of $\mathrm{Ag}$, which is a background element, were analyzed. A major chemical category was derived based on the four most abundant elements classified as EDS spectra at the same location in three specimens in repetition $[48,49]$. In order to identify the classified representative metal compounds, SEM (EM-30, COXEM, Daejeon, Korea) and EDS (Xplore, Oxford, England) were used, and the weight ratio of each analyzed particle was analyzed to examine whether the element was included. In order to secure the reliability of EDS-based chemical species analysis, a verified standard sample [7] (Micro-Analysis Consultants LTD) was used to conduct the spectral location standard and quantification calibration.

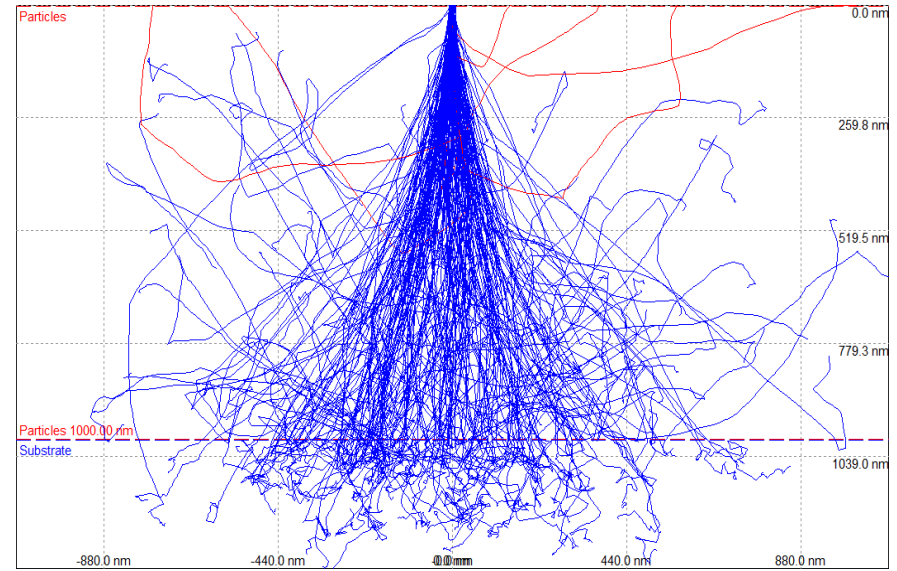

(a)

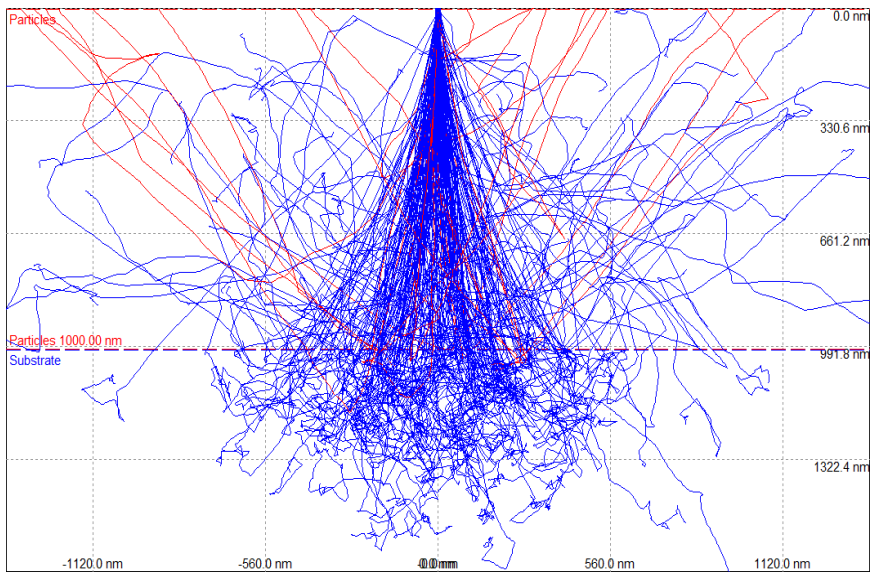

(b)

Figure 2. Monte Carlo simulation for accelerating voltage (AV) optimization of SEM-EDS (a) AV: $15 \mathrm{kV}$, interaction volume: depth $=1.0 \mu \mathrm{m},(\mathbf{b}) \mathrm{AV}: 20 \mathrm{kV}$, interaction volume: depth $=1.3 \mu \mathrm{m}$.

\section{Results and Discussion}

\subsection{Conditions for Specimen and Test}

The conditions for the incineration environment were reviewed by classifying them into the incineration time, the incineration weight, the average incineration airflow, the number of particles, and the average incineration gas temperature (Table 1). The incineration time was counted differently depending on the sample, and it is believed that the difference in soil or adsorbed material on the sample surface affected the time at which incineration was terminated. The actual incineration weight of the sample through the test was 128.2 130.7 g, which is considered to have been incinerated at a similar amount. The blower (input power/power consumption: $260 \mathrm{~W} / 432 \mathrm{~W}$, maximum positive pressure: $34 \mathrm{mmAq}$ ) applied to the test infrastructure was equally operated at the minimum operating range, but the average incineration airflow had a tendency to decrease as the incineration time increased. As for the number of particles calculated through the Auto- 
mated SEM-EDS method, 19,656 particles were identified in the tertiary sample that was incinerated for the longest time, and the average incineration gas temperature was also the highest at $87.55^{\circ} \mathrm{C}$. BS ISO 13322-1:2014 [48] and NIST [49] recommend measuring about 10,000 particles for statistical robustness, determined by the relative standard deviation of morphological shape descriptors such as particle size and shape coefficients. In this study, we tried to obtain the statistical significance by analyzing 12,364 19,656 particles above this number.

Table 1. Conditions for incineration experiment of waste mulching LDPE collected in DangJin.

\begin{tabular}{ccccc}
\hline \multirow{2}{*}{ Measurement } & Unit & \multicolumn{3}{c}{ Repeat } \\
\cline { 3 - 5 } & & 1st & 2nd & 3rd \\
\hline Time & $\mathrm{min}$ & 11.57 & 15.12 & 17.1 \\
Weight & $\mathrm{g}$ & 127 & 128.2 & 128.2 \\
Avg. Airflow & $\mathrm{m}^{3} / \mathrm{min}$ & 0.46 & 0.84 & 0.54 \\
Particles & ea & 14,296 & 12,364 & 19,656 \\
Avg. gas & ${ }^{\circ} \mathrm{C}$ & 74.31 & 83.37 & 87.55 \\
temperature & & & & \\
\hline
\end{tabular}

\subsection{Major Chemical Categories by Particle Diameter}

This study classified the chemical compounds depending on $\mathrm{D}_{\mathrm{p}}$ (aerodynamic diameter), based on the major metals of the metal compounds detected in particulate pollutants emitted from incineration of waste mulching LDPE (Table 2). The criteria were divided into $1.0 \mu \mathrm{m}<\mathrm{D}_{\mathrm{p}} \leq 2.5 \mu \mathrm{m}, 2.5 \mu \mathrm{m}<\mathrm{D}_{\mathrm{p}} \leq 10 \mu \mathrm{m}, 10 \mu \mathrm{m}<\mathrm{D}_{\mathrm{p}} \leq 50 \mu \mathrm{m}$ referring to the fine dust classification system, and single-element, two-element, three-element, four-element, and other were categorized based on the general approach of the individual particles. LDPE, an incineration material, can be converted into a carbon material in the form of LLDPE (linear low-density polyethylene) through thermal oxidation in the range of 270 to $330{ }^{\circ} \mathrm{C}$ air [38]. In this study, among particulate matter detected from incineration of waste mulching LDPE, black carbon (mean $=10,172$ ), a major component of soot, was the absolute majority, and a large number of carbon oxides (mean $=1318$ ) were also identified. The following is an automated SEM-EDS analysis image (Figure 3) with a total of 48 fields superimposed on $1024 \times 720$ pixels by field for each sample, and the analysis results are summarized in Table 2 below.

Fe $($ mean $=81.3)$ and $\mathrm{Cu}($ mean $=22)$ were identified as transition metals among the metallic particulate matter detected from the incineration test, and $\mathrm{Al}$ (mean = 116.7) was detected as other metals. In addition, as for metals for which the number of particles at a significant level was confirmed, $\mathrm{Ca}$ (mean =52) and $\mathrm{Mg}$ (mean =4.7) as alkaline earth metals were detected, and $\mathrm{Na}($ mean $=7.3)$ and $\mathrm{K}($ mean $=3)$ as alkali metals were identified. An average of 173 trace metals and nonmetals were also detected.

Particles containing all types of metal elements, such as detected transition metals and other metals, showed a high frequency in the range of $2.5 \mu \mathrm{m}<\mathrm{D}_{\mathrm{p}} \leq 10 \mu \mathrm{m}$, and major metal elements were counted at a high ratio of $\mathrm{C}-\mathrm{O}$ compounds. The dominant phase of Fe among the transition metals was identified as Fe-C-O (mean = 59), which is a three-element category, and the most particles were detected in the $2.5 \mu \mathrm{m}<\mathrm{D}_{\mathrm{p}} \leq 10 \mu \mathrm{m}$ range. The dominant phase of $\mathrm{Cu}$ was identified as $\mathrm{Cu}-\mathrm{C}-\mathrm{O}$ (mean = 12), which is a three-element category, and the most particles were detected in the $2.5 \mu \mathrm{m}<\mathrm{D}_{\mathrm{p}} \leq 10 \mu \mathrm{m}$ range, similarly to Fe. The dominant phase of $\mathrm{Al}$, which is detected to be in the category of other metals, was identified as Al-CO-Si (mean =52.3), which is in the four-element category, and the most particles were detected in the $2.5 \mu \mathrm{m}<\mathrm{D}_{\mathrm{p}} \leq 10 \mu \mathrm{m}$ range, similarly to transition metals. It is inferred to have reacted with $\mathrm{SiO} 2$, the second most abundant mineral after feldspar in the crust, and $\mathrm{SiO} 2$ is a common mineral found in river sediments and soil residues due to its resistance to weathering [13]. 
Table 2. Major chemical categories and their normalized average particles (size: $1 \mu \mathrm{m}<\mathrm{Dp}$ ) of metal compound from incineration experiment of waste mulching LDPE collected in DangJin (unit: ea).

\begin{tabular}{|c|c|c|c|c|c|}
\hline Class & Subclass & Total & $\begin{array}{c}1.0 \mu \mathrm{m}<\mathrm{D}_{\mathrm{p}} \leq \\
2.5 \mu \mathrm{m}\end{array}$ & $\begin{array}{c}2.5 \mu \mathrm{m}<\mathrm{D}_{\mathrm{p}} \leq \\
10 \mu \mathrm{m}\end{array}$ & $\begin{array}{c}10 \mu \mathrm{m}<\mathrm{D}_{\mathrm{p}} \leq \\
50 \mu \mathrm{m}\end{array}$ \\
\hline \multirow{9}{*}{$\mathrm{Al}$} & $\mathrm{Al}$ & 1.6 & $0.3 \pm 0.5$ & $1.3 \pm 1.9$ & ND \\
\hline & Al-C & 8.7 & $1.7 \pm 2.4$ & $6.7 \pm 9.4$ & $0.3 \pm 0.5$ \\
\hline & $\mathrm{Al}-\mathrm{C}-\mathrm{O}$ & 27.7 & $8.7 \pm 12.3$ & $19 \pm 26.9$ & ND \\
\hline & Al-C-O-Cl & 4.4 & $1.7 \pm 2.4$ & $2.7 \pm 3.1$ & ND \\
\hline & Al-C-O-Si & 52.4 & $7.7 \pm 2.1$ & $23 \pm 11.9$ & $21.7 \pm 14.4$ \\
\hline & Al-O & 4.3 & $2 \pm 2.8$ & $2 \pm 2.8$ & $0.3 \pm 0.5$ \\
\hline & Al-O-Si & 13.3 & $1.3 \pm 1.2$ & $5.7 \pm 4.6$ & $6.3 \pm 6.2$ \\
\hline & Other & 4.3 & $0.3 \pm 0.5$ & $3.3 \pm 2.4$ & $0.7 \pm 0.9$ \\
\hline & Total & 116.7 & 23.7 & 63.7 & 29.3 \\
\hline \multirow{8}{*}{$\mathrm{Ca}$} & $\mathrm{Ca}-\mathrm{C}$ & 2 & $0.7 \pm 0.9$ & $1.3 \pm 0.9$ & ND \\
\hline & $\mathrm{Ca}-\mathrm{C}-\mathrm{O}$ & 34.3 & $5 \pm 4.5$ & $24.3 \pm 26.4$ & $5 \pm 6.4$ \\
\hline & $\mathrm{Ca}-\mathrm{O}$ & 3 & $0.3 \pm 0.5$ & $2 \pm 2.2$ & $0.7 \pm 0.9$ \\
\hline & $\mathrm{Ca}-\mathrm{O}-\mathrm{Si}$ & 0.6 & ND & $0.3 \pm 0.5$ & $0.3 \pm 0.5$ \\
\hline & Ca-C-Si & 0.3 & ND & $0.3 \pm 0.5$ & ND \\
\hline & $\mathrm{Ca}-\mathrm{C}-\mathrm{O}-\mathrm{Si}$ & 2.7 & $0.7 \pm 0.5$ & $1 \pm 0.8$ & $1 \pm 1.4$ \\
\hline & Other & 9 & $1.7 \pm 0.5$ & $6 \pm 4.1$ & $1.3 \pm 1.2$ \\
\hline & Total & 51.9 & 8.4 & 35.2 & 8.3 \\
\hline \multirow{7}{*}{$\mathrm{Cu}$} & $\mathrm{Cu}$ & 0.6 & $0.3 \pm 0.5$ & $0.3 \pm 0.5$ & ND \\
\hline & $\mathrm{Cu}-\mathrm{C}$ & 4.7 & ND & $3 \pm 2.9$ & $1.7 \pm 2.4$ \\
\hline & $\mathrm{Cu}-\mathrm{C}-\mathrm{O}$ & 12.1 & $2.7 \pm 3.8$ & $6.7 \pm 8.7$ & $2.7 \pm 3.8$ \\
\hline & $\mathrm{Cu}-\mathrm{C}-\mathrm{O}-\mathrm{Cl}$ & 3.3 & $0.7 \pm 0.9$ & $2.3 \pm 2.1$ & $0.3 \pm 0.5$ \\
\hline & $\mathrm{Cu}-\mathrm{C}-\mathrm{O}-\mathrm{Si}$ & 0.7 & ND & $0.7 \pm 0.9$ & ND \\
\hline & Other & 0.6 & ND & $0.3 \pm 0.5$ & $0.3 \pm 0.5$ \\
\hline & Total & 22 & 3.7 & 13.3 & 5 \\
\hline \multirow{9}{*}{$\mathrm{Fe}$} & $\mathrm{Fe}$ & 1 & $0.3 \pm 0.5$ & $0.7 \pm 0.5$ & ND \\
\hline & $\mathrm{Fe}-\mathrm{C}$ & 7 & $2.3 \pm 2.1$ & $4 \pm 3.7$ & $0.7 \pm 0.9$ \\
\hline & $\mathrm{Fe}-\mathrm{C}-\mathrm{O}$ & 59 & $5.3 \pm 3.1$ & $42.7 \pm 30.7$ & $11 \pm 9$ \\
\hline & $\mathrm{Fe}-\mathrm{C}-\mathrm{O}-\mathrm{Cl}$ & 0.6 & $0.3 \pm 0.5$ & $0.3 \pm 0.5$ & ND \\
\hline & $\mathrm{Fe}-\mathrm{C}-\mathrm{O}-\mathrm{Cr}$ & 1 & $0.3 \pm 0.5$ & $0.7 \pm 0.9$ & ND \\
\hline & $\mathrm{Fe}-\mathrm{O}$ & 8 & $1.3 \pm 0.9$ & $5 \pm 3.7$ & $1.7 \pm 1.2$ \\
\hline & $\mathrm{Fe}-\mathrm{O}-\mathrm{Cr}$ & 0.3 & ND & $0.3 \pm 0.5$ & ND \\
\hline & Other & 4.3 & $0.3 \pm 0.5$ & $3.3 \pm 2.9$ & $0.7 \pm 0.5$ \\
\hline & Total & 81.2 & 10.1 & 57 & 14.1 \\
\hline \multirow{5}{*}{ K } & K & 2 & $0.7 \pm 0.9$ & $1.3 \pm 1.2$ & ND \\
\hline & $\mathrm{K}-\mathrm{C}$ & 0.3 & ND & $0.3 \pm 0.5$ & ND \\
\hline & $\mathrm{K}-\mathrm{O}$ & 0.3 & $0.3 \pm 0.5$ & ND & ND \\
\hline & Other & 0.3 & $0.3 \pm 0.5$ & ND & ND \\
\hline & Total & 2.9 & 1.3 & 1.6 & ND \\
\hline \multirow{5}{*}{$\mathrm{Mg}$} & $\mathrm{Mg}$ & 0.3 & ND & $0.3 \pm 0.5$ & ND \\
\hline & $\mathrm{Mg}-\mathrm{C}$ & 0.3 & ND & $0.3 \pm 0.5$ & ND \\
\hline & $\mathrm{Mg}-\mathrm{C}-\mathrm{O}$ & 2.3 & $1 \pm 0.8$ & $1 \pm 0.8$ & $0.3 \pm 0.5$ \\
\hline & Other & 1.6 & ND & $1.3 \pm 0.9$ & $0.3 \pm 0.5$ \\
\hline & Total & 4.5 & 1 & 2.9 & 0.6 \\
\hline \multirow{4}{*}{$\mathrm{Na}$} & $\mathrm{Na}-\mathrm{C}$ & 0.3 & ND & $0.3 \pm 0.5$ & ND \\
\hline & $\mathrm{Na}-\mathrm{C}-\mathrm{O}$ & 2 & $0.3 \pm 0.5$ & $1 \pm 1.4$ & $0.7 \pm 0.9$ \\
\hline & Other & 5 & $1 \pm 0.8$ & $3.7 \pm 2.1$ & $0.3 \pm 0.5$ \\
\hline & Total & 7.3 & 1.3 & 5 & 1 \\
\hline
\end{tabular}
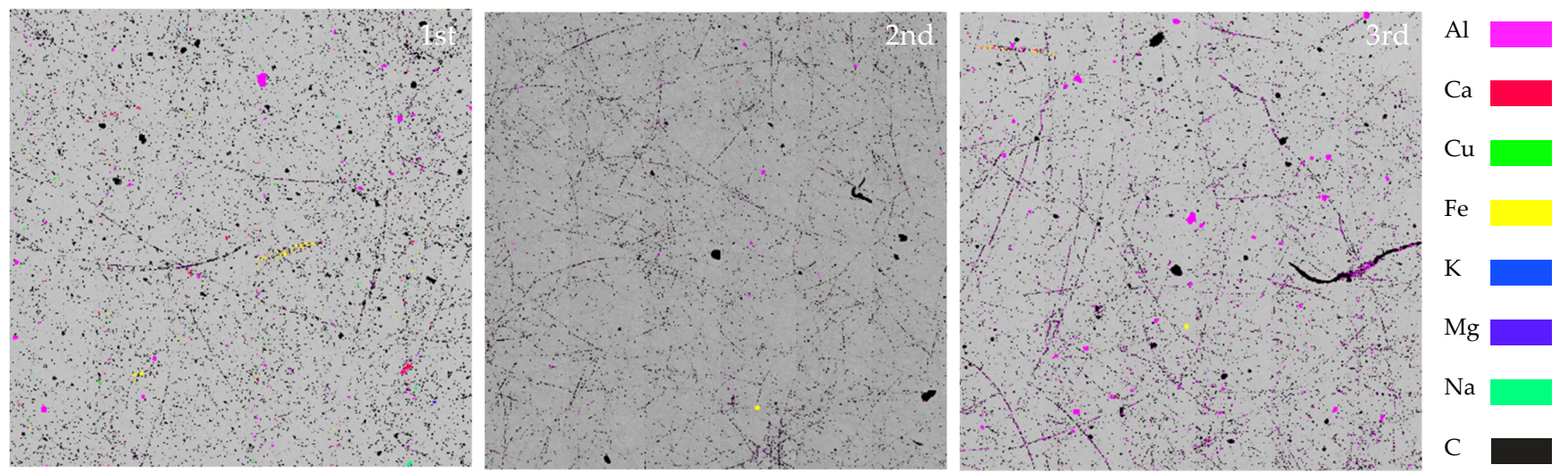

Figure 3. Surface of the 1st, 2nd, and 3rd samples (BSE image).

The major transition metals and other metals discharged from incineration of waste mulching LDPE were $\mathrm{Fe}, \mathrm{Cu}$, and $\mathrm{Al}$, with more than 20 particles identified, and the order of the number of detected particles was $\mathrm{Al}>\mathrm{Fe}>\mathrm{Cu}$ (Figure 4). This order is thought to be influenced by the composition of the pollutant sources and the bond dissociation energies 
(BDEs), which is an intrinsic property of the metal species. That is, it can be seen that the metal species with the higher BDEs with carbon or oxygen could exist in the particulates in a relatively large amount [50].

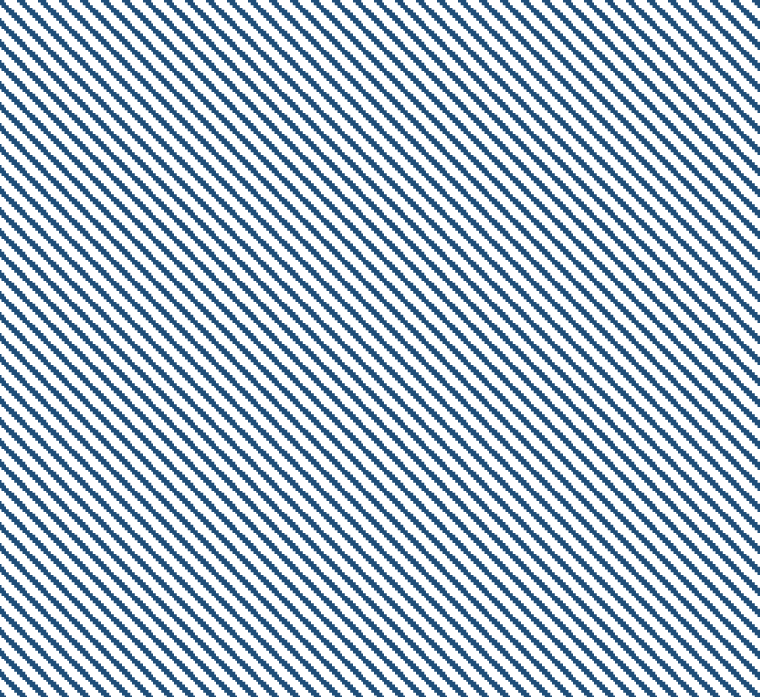

Figure 4. Composition ratio of metal particles discharged from incineration experiment of waste mulching LDPE.

\subsection{Analysis of Transition Metals and Other Metals}

Among transition metals, Fe was found to have the largest number of particles (mean $=12.0$ ) in $4 \mu \mathrm{m}<\mathrm{D}_{\mathrm{p}} \leq 5 \mu \mathrm{m}$ in the range of $2.5 \mu \mathrm{m}<\mathrm{D}_{\mathrm{p}} \leq 10 \mu \mathrm{m}$. As for the particles observed in the $\mathrm{D}_{\mathrm{p}}$ range, Fe-C-O was the most abundant in the three-element category and the dominant phase (Figure 5). In addition to the dominant phase, metal compounds such as Fe-O (mean $=8)$ and F-C (mean $=7)$ were mainly detected.

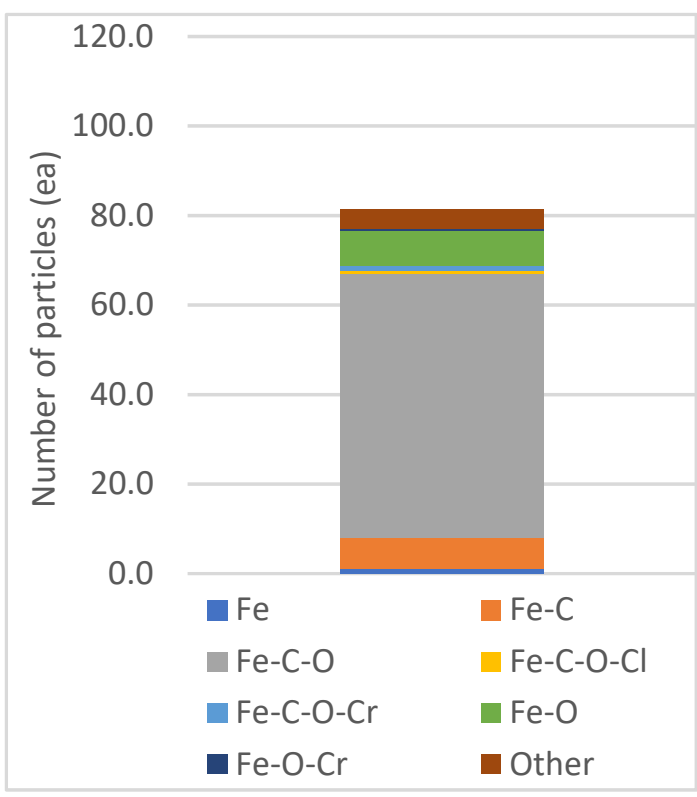

(a)

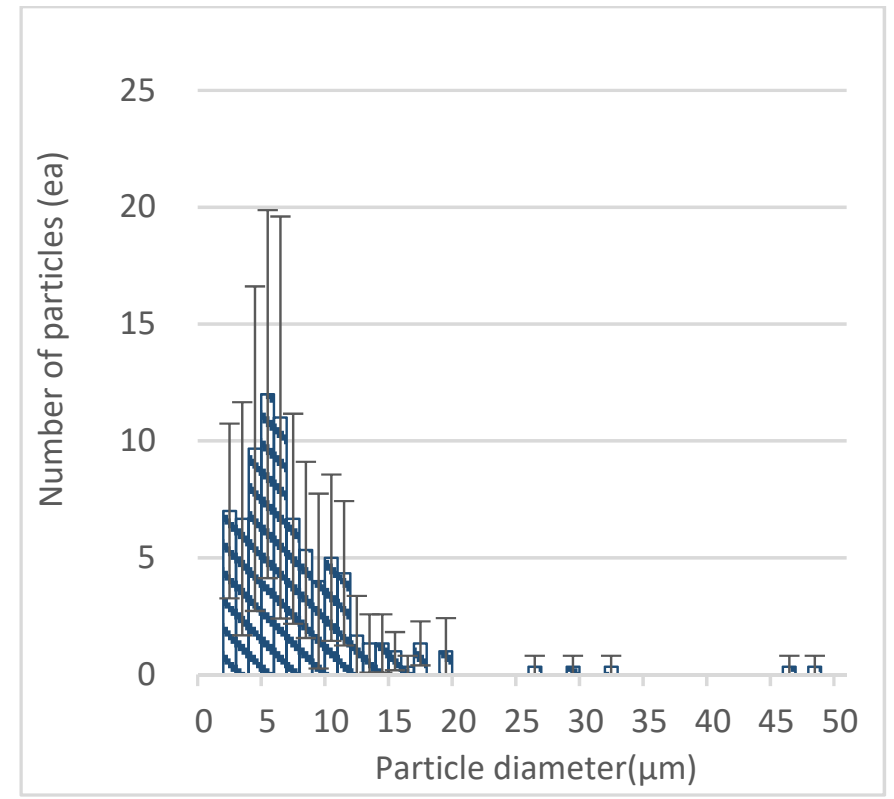

(b)

Figure 5. Composition of chemical categories and number of total Fe particles: (a) Composition of chemical categories; (b) number of total Fe particles by aerodynamic diameter $(\mu \mathrm{m})$. 
PE (polyethylene), a representative rubbery plastic, has a high adsorption capacity and is known to effectively absorb metal ions through degradation [5]. Minerals detected from recycled agricultural plastic materials through BSE analysis were identified as a single element or an oxide rich in $\mathrm{Zn}$ and Fe [13]. Therefore, it is considered that the incineration of LDPE created an inert atmosphere through the thermal oxidation process, the calcined LDPE was converted into a carbon material, and the Fe derived from the soil adsorbed on LDPE reacted with $\mathrm{C}-\mathrm{O}$ and $\mathrm{C}$ compounds.

Among the transition metals, $\mathrm{Cu}$ had the largest number of particles (mean $=4.0$ ) of $4 \mu \mathrm{m}<\mathrm{D}_{\mathrm{p}} \leq 5 \mu \mathrm{m}$ in the range of $2.5 \mu \mathrm{m}<\mathrm{D}_{\mathrm{p}} \leq 10 \mu \mathrm{m}$, and as for the particles observed in the $\mathrm{D}_{\mathrm{p}}$ range, $\mathrm{Cu}-\mathrm{C}-\mathrm{O}$ was the most abundant in the three-element category and the dominant phase (Figure 6). In addition to the dominant phase, metal compounds such as $\mathrm{Cu}-\mathrm{C}($ mean $=4.7)$ and $\mathrm{Cu}-\mathrm{C}-\mathrm{O}-\mathrm{Cl}($ mean $=3.3)$ were mainly detected. Copper oxide is widely used to impregnate AC (activated carbon) [51,52]. The impregnating mechanism is made by clogging of well-developed pores of AC by copper oxide particles after calcination at $450^{\circ} \mathrm{C}$ [51]. In addition, through BSE analysis of recycled agricultural plastic materials, it has been reported that all materials contain abundant chlorine, such as $\mathrm{KCl}$ and $\mathrm{NaCl}$ [13]. Therefore, it is considered that the calcined LDPE was converted into a carbon material, and that $\mathrm{Cu}$ and $\mathrm{Cl}$ derived from soil adsorbed on LDPE reacted with $\mathrm{CO}$ and $\mathrm{C}$ compounds.

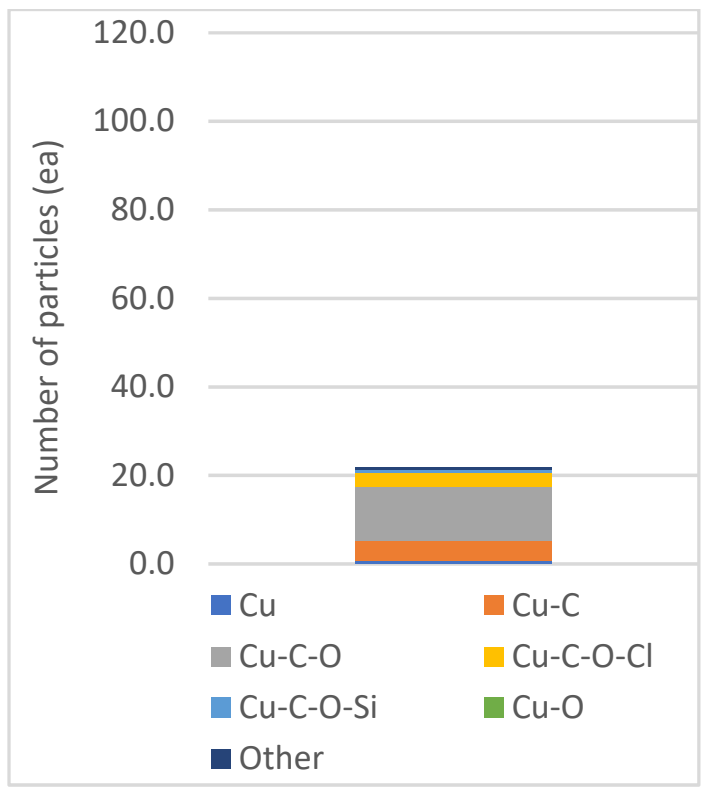

(a)

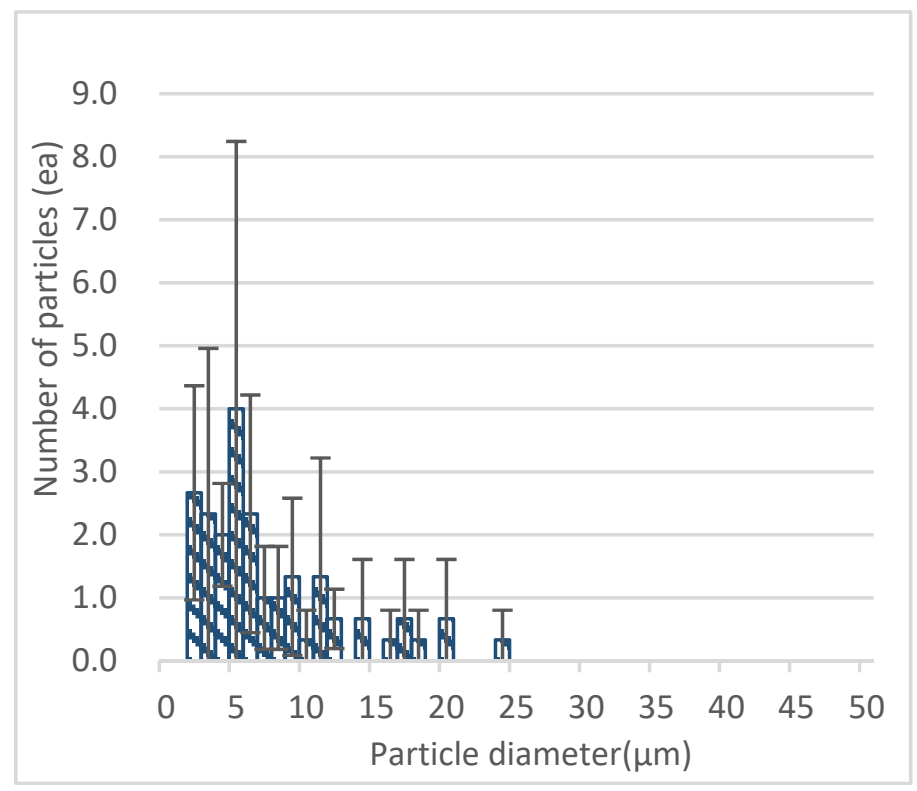

(b)

Figure 6. Composition of chemical categories and number of total $\mathrm{Cu}$ particles: (a) Composition of chemical categories; (b) number of total $\mathrm{Cu}$ particles by aerodynamic diameter $(\mu \mathrm{m})$.

$\mathrm{Al}$ detected as other metals was found to have the largest number of particles (mean $=18.3$ ) of $1 \mu \mathrm{m}<\mathrm{D}_{\mathrm{p}} \leq 2 \mu \mathrm{m}$, not in the range of $2.5 \mu \mathrm{m}<\mathrm{D}_{\mathrm{p}} \leq 10 \mu \mathrm{m}$. As for the particles observed in the $\mathrm{D}_{\mathrm{p}}$ range, $\mathrm{AI}-\mathrm{C}-\mathrm{O}-\mathrm{Si}$ was the most abundant in the four-element category and the dominant phase (Figure 7). In addition to the dominant phase, metal compounds such as Al-C-O (mean = 27.7) and Al-O-Si (mean = 13.3) were mainly detected. In addition to the dominant phase, many particles composed of Si-O compounds were found, suggesting that they reacted with $\mathrm{SiO}_{2}$, a mineral abundant in the soil. In addition, feldspars containing aluminum and kaolinite $\left(\mathrm{Al}_{2} \mathrm{Si}_{2} \mathrm{O}_{5}(\mathrm{OH})_{4}\right)$ were detected in BSE analysis of recycled agricultural plastic matters [13]. Therefore, it is considered that calcined LDPE was converted into carbon material, and that $\mathrm{Al}$ and $\mathrm{Si}$ derived from soil adsorbed on LDPE reacted with $\mathrm{C}-\mathrm{O}$ and $\mathrm{C}$ compounds. Particulate matter that is inhaled from the nasal passages and into the airways can penetrate deep into the alveoli due to excessive permeability [53]. Particles with a diameter of about 5 to $10 \mu \mathrm{m}$ are deposited the most in the tracheobronchial tree, 
whereas particles with a diameter of 1 and $5 \mu \mathrm{m}$ are deposited up to respiratory bronchioles and alveoli, where gas exchange occurs [54]. Particles of this size can penetrate the lungs by affecting gas exchange within the lungs, where they eventually escape into the blood stream and cause serious health problems [55]. Transition metals and other metals which were detected at a high rate in particulate pollutants emitted by incineration of mulching LDPE in this study were Fe $\left(4 \mu \mathrm{m}<\mathrm{D}_{\mathrm{p}} \leq 5 \mu \mathrm{m}\right), \mathrm{Cu}\left(4 \mu \mathrm{m}<\mathrm{D}_{\mathrm{p}} \leq 5 \mu \mathrm{m}\right), \mathrm{Al}\left(1 \mu \mathrm{m}<\mathrm{D}_{\mathrm{p}} \leq 2 \mu \mathrm{m}\right)$, and it is considered that all of these types of metallic particulate matter can have a negative effect on health by depositing in respiratory bronchioles and alveoli.

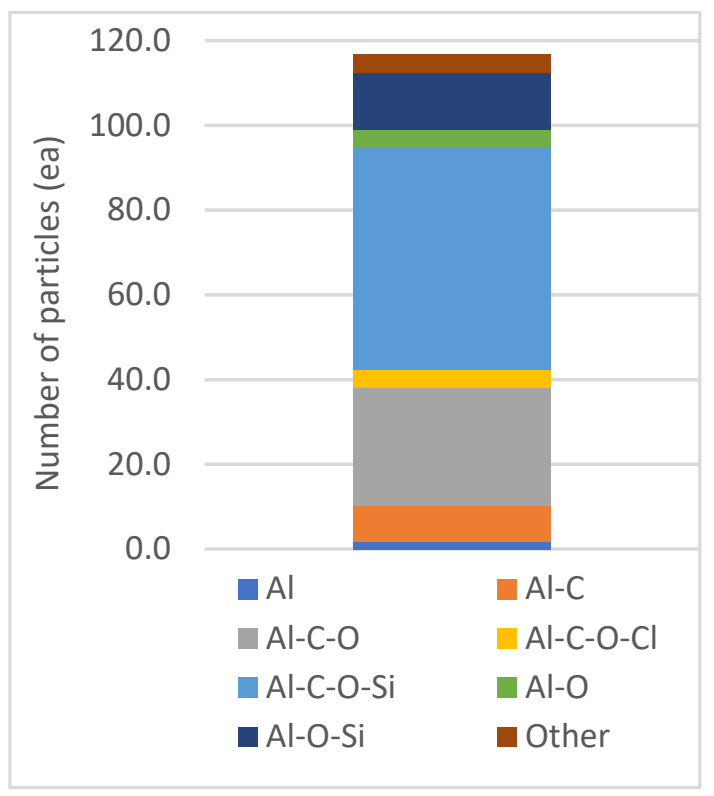

(a)

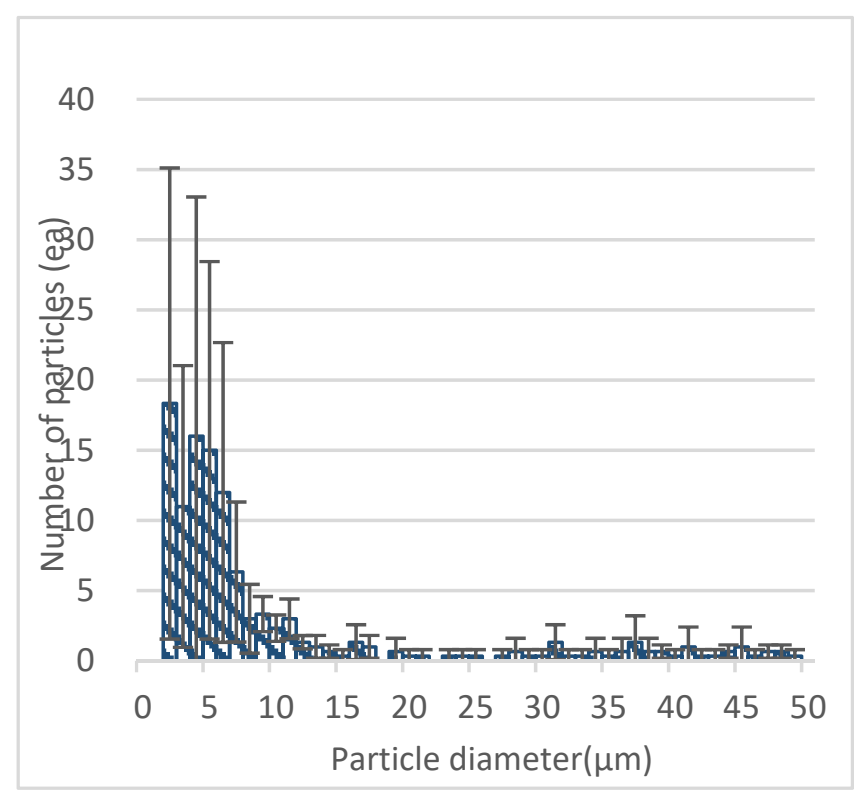

(b)

Figure 7. Composition of chemical categories and number of total Al particles: (a) Composition of chemical categories; (b) number of total Al particles by aerodynamic diameter $(\mu \mathrm{m})$.

BSE analysis was used to derive the chemical compounds by analyzing the distribution of various elements in the specimen, and SE (secondary electron) analysis was used to calculate the particle diameter by analyzing the shape of the specimen. $\mathrm{Fe}, \mathrm{Cu}$, and $\mathrm{Al}$, which were detected as having the largest number of particles among major transition metals and other metals discharged from incineration of waste mulching LDPE, were manually counted on a particle basis under the condition of $20 \mathrm{kV}$ electron acceleration.

Figure 8 shows the spectral distribution curves of typical transition metals and other metal particles identified in the specimen, and the weight ratio was measured by removing $\mathrm{Ag}$, a background element. An even weight ratio of $\mathrm{C}$ and $\mathrm{O}$ was identified for all of the analyzed metal particles. The particles identified with Fe were $3.6 \mu \mathrm{m}$ and corresponded to $\mathrm{Fe}-\mathrm{C}-\mathrm{O}-\mathrm{Cl}$, the four-element category, and $\mathrm{C}(45.7 \mathrm{wt} \%), \mathrm{O}(26.6 \mathrm{wt} \%)$, and $\mathrm{Fe}(14.6 \mathrm{wt} \%)$ were at a high weight ratio. The particles containing $\mathrm{Cu}$ were $5.1 \mu \mathrm{m}$ and corresponded to $\mathrm{Cu}-\mathrm{C}-\mathrm{O}-\mathrm{Cl}$, the four-element category, and $\mathrm{C}(51.9 \mathrm{wt} \%), \mathrm{Cu}(29.2 \mathrm{wt} \%)$, and $\mathrm{O}(12.5 \mathrm{wt} \%)$ were at a high weight ratio. The particles containing AI were $7.2 \mu \mathrm{m}$ and corresponded to Al-C-O-Si, the other category, which includes Fe in the four-elementary category, and $\mathrm{O}$ (52.0 wt \%), C (23.8 wt\%), Si (11.6 wt\%), Al (8.1 wt\%) were at a high weight ratio. Significant amounts of $\mathrm{Cl}$ were identified in $\mathrm{Fe}$ and $\mathrm{Cu}$, which are transition metals, and $\mathrm{Al}$, which is in the other metals category, reacted with $\mathrm{Si}$. The detection of transition metals and other metal particles in calcined waste mulching LDPE is considered to be attributed to the high metal content of the degraded LDPE. Jemec Kokalj et al. found a 400 times higher Fe concentration in recycled LDPE than that in virgin LDPE, and a 12 times higher concentration of $\mathrm{Cu}$, a toxic metal, through TXRF analysis [56]. Thipse et al. incinerated newsprint paper, hardwood mulch, LDPE, iron, animal feed and sand for simulating 
MSW (municipal solid waste), and found that smaller particles adhered to the surface of large monolithic particles through SEM-EDS analysis of the discharged ash particles. In addition, oxygen and chlorine were detected in almost all ash particles discharged from MSW incineration, and strong peaks of $\mathrm{Fe}, \mathrm{Al}$, and $\mathrm{Si}$ were also identified [57]. In this study, as shown in (a) and (b), it was observed that smaller particles were attached to the surface around monolithic particles (Figure 8). Additionally, with the exception of $\mathrm{Cu}$, the calcined waste mulching LDPE was found to have elemental properties similar to ash particles discharged from MSW incineration. Through this experiment, it is verified that the metal absorption rate was increased due to the deterioration caused by mulching LDPE, the metal chemicals originating from the soil were adsorbed, and significant metal chemicals were identified in the particulate matter discharged from incineration.
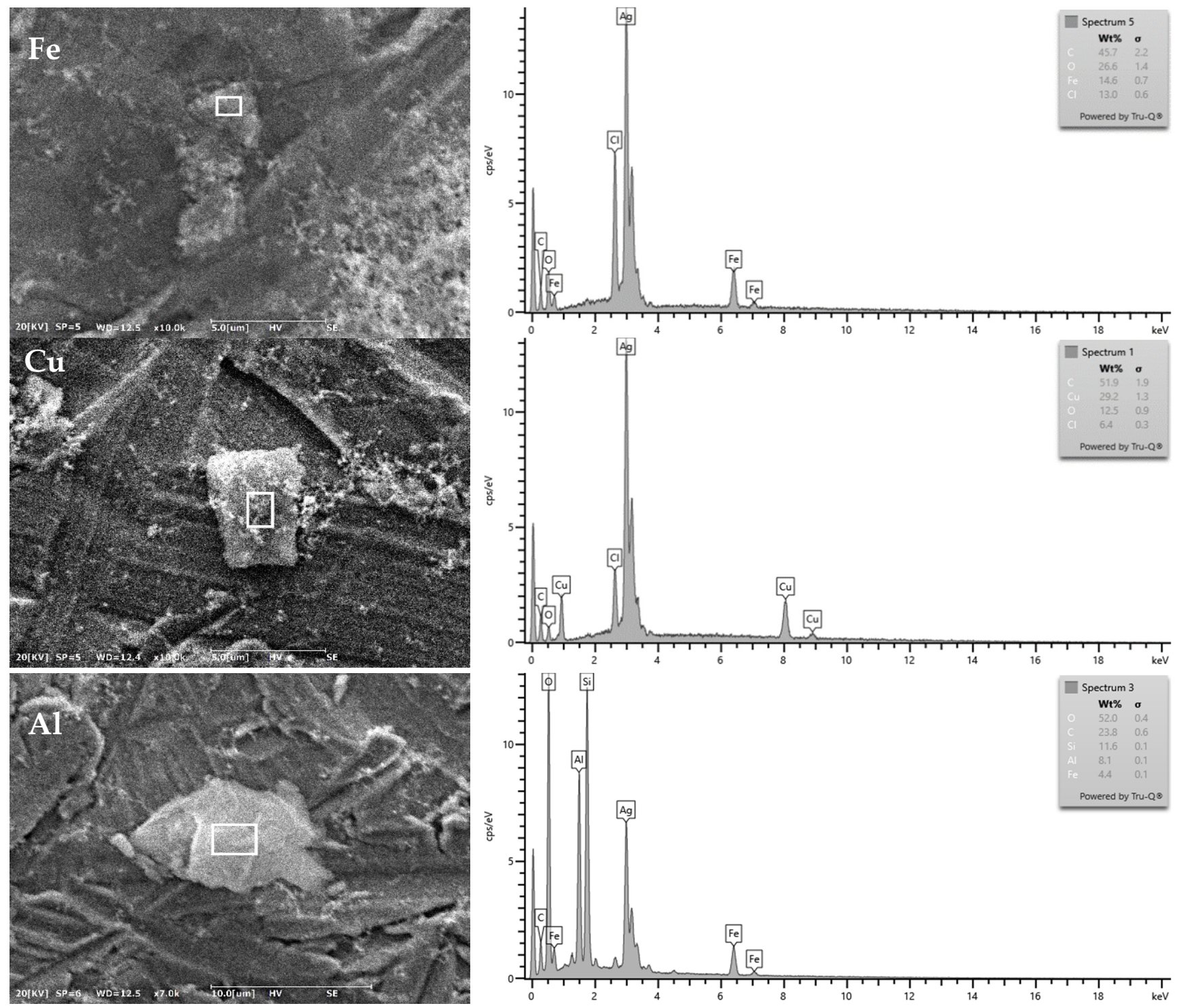

Figure 8. SEM-EDS elemental analysis of metal particles from incineration experiment of waste LDPE film collected in DangJin.

The metal particulate matter detected through this study showed a high reaction to $\mathrm{C}$ and $\mathrm{C}-\mathrm{O}$, and the ratio was high as for transition metals and heavy metals (HMs). The ratio of metal particulate matter that reacted with $\mathrm{C}$ and $\mathrm{C}-\mathrm{O}$ was in the order of $\mathrm{Cu}(94.1 \%)>\mathrm{Fe}$ $(83.3 \%)>\mathrm{Al}(79.7 \%)$. 
First, LDPE is a carbon-based polymer without heteroatoms, with a crystallinity of about $60 \%, \mathrm{Tg}$ (glass transition temperature) of $-25^{\circ} \mathrm{C}$, and crystal melting point of $109-125^{\circ} \mathrm{C}$ [58]. As for the domestically produced LDPE, the spontaneous ignition temperature is $330-410{ }^{\circ} \mathrm{C}$ [59]. Like polyacrylonitrile, LDPE can be converted into a carbon material in an inert atmosphere after thermal oxidation in air of 270 to $330{ }^{\circ} \mathrm{C}$ in the form of LDPE [60].

In addition, Alabi-Babalola et al. produced $\mathrm{AC}$ (activate carbon) such as $\mathrm{H}_{2} \mathrm{SO}_{4}$ and $\mathrm{KOH}$ from LDPE, and burned it at $400-500{ }^{\circ} \mathrm{C}$. Carbon produced in the combustion process has a high adsorption affinity for inorganic ions such as $\mathrm{Mn}^{7+}, \mathrm{Co}^{2+}$ and $\mathrm{Cr}^{6+}$ [61] Therefore, the large amount of $\mathrm{C}$ and $\mathrm{C}-\mathrm{O}$ in the metal chemicals identified in this study can be considered as the effect of carbonization and high adsorption affinity for inorganic ions at the appropriate ignition temperature of LDPE.

In addition, plastics are divided into rubbery plastics and glassy plastics depending on $\mathrm{Tg}$, and PE and PP are rubbery plastics [62]. Rubbery plastics have a large amount of free volume between molecules [63]. This provides a lot of space to adsorb the material. LDPE is a PE-based rubbery plastic that can adsorb various organic pollutants and metal pollutants, and it has been found that $\mathrm{Cu}$ and $\mathrm{Zn}$ are adsorbed on polyethylene (PE) and polyvinyl chloride (PVC) [64]. This can be interpreted more specifically as a result of research [5] finding that it more effectively absorbs metal ions through deterioration compared to unused plastics. Therefore, it is considered that a lot of metal chemicals derived from soil were adsorbed to the LDPE for waste mulching before incineration due to its own physical properties of LDPE confirmed in this study and the deterioration generated during the process of crop cultivation. It is considered that this may be included in the particulate pollutants discharged from incineration and may affect the atmosphere.

Among particulate pollutants discharged from incineration of waste mulching LDPE, $\mathrm{HMs}$ such as $\mathrm{Cu}, \mathrm{Fe}$, and $\mathrm{Al}$ were detected as major transition metals and other metals. Excessive accumulation of HMs affects soil quality, and HMs produced in significant amounts by man-made emissions are serious environmental pollutants causing toxicity, persistence and biological accumulation $[65,66]$. Transition metals may generate ROS in organisms, which are involved in the complex balance of the control mechanisms that contribute to survival or death of cells through intercellular signal transmission and chemical communication between cells. While normal levels of ROS are essential for normal physiological function, excessive levels that inhibit antioxidation lead to chronic cardiovascular, neurodegenerative and metabolic disorders along with infection and inflammation [67]. Transition metals such as $\mathrm{Fe}, \mathrm{Cu}, \mathrm{Ni}$ and $\mathrm{Cr}$ also affect oxidative stress in biological tissues. Oxidative stress is generated when the antioxidant system is degraded by oxidation, and also by redox cycling caused by semiquinone radicals of ROS produced by organic compounds adsorbed to particles and activated macrophages [9]. Therefore, this study confirmed that transition metals including HMs and other metals that could affect human toxicity by activating or reducing transition metals were discharged from incineration of waste mulching LDPE.

Meanwhile, the cause of the binding of metal species to carbon particles after the incineration of the waste LDPE film can be explained by the following process. Binda et al. pointed out polymer degradation as a cause of promoting the interaction with metals on the surface of microplastics [68]. The degradation of these polymers can result in an increase in oxidized functional groups, surface charges, surface area, and reactive sites. In particular, the oxidized functional groups generated due to degradation make the polymer surface hydrophilic, and simultaneously cause coordination bonds with metals. Additionally, Krehula et al. demonstrated that polyethylene could be decomposed under outdoor climate conditions to form carbonyl and vinyl groups, as shown in Figure 9a [69]. Therefore, as shown in Figure 9b,c, degradation of LDPE occurs, which may promote interaction between metal components and LDPE (coordination bonding and electrostatic attraction, etc.) As a result, it is considered that the metal compound combined with carbon is finally included in the particles, as shown in Figure 9d, after incinerating the waste plastic film. 
(a)
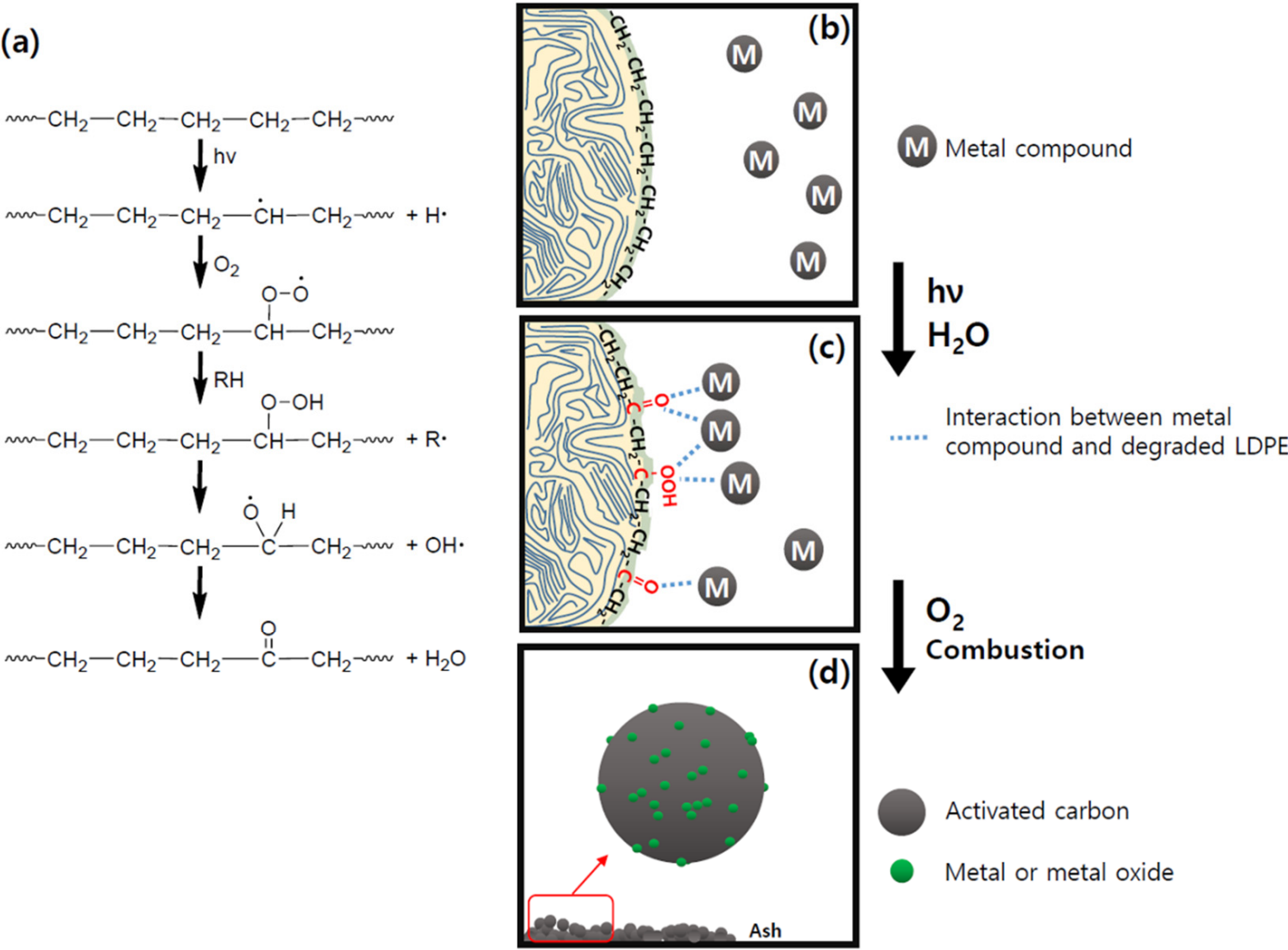

Figure 9. The process of combining LDPE and metal compound [62,63]: (a) Degradation mechanism of LDPE and schematic drawings of (b) non-degraded LDPE surface non-coordinated with metal compounds, (c) degraded LDPE surface coordinated with metal compounds, and (d) metal bounded carbon particles formed after calcination.

\section{Conclusions}

In this study, waste mulching LDPE collected at the Korea Environment \& Resources Corporation's Dangjin Office was incinerated, and particulate matter containing metal compounds harmful to the human body was analyzed. Using automated SEM-EDS, it was possible to effectively check whether or not metal compounds in incinerated particulate pollutants were detected by analyzing the number, chemical composition, shape and weight ratio of each particle size of transition metals and other metals. As for transition metals and other metals, a large amount of $\mathrm{Fe}, \mathrm{Cu}$, and $\mathrm{Al}$ were detected in the range of $4 \mu \mathrm{m}<\mathrm{D}_{\mathrm{p}} 55$ $\mu \mathrm{m}(\mathrm{Fe}, \mathrm{Cu})$ and $1 \mu \mathrm{m}<\mathrm{D}_{\mathrm{p}} 2 \mu \mathrm{m}(\mathrm{Al})$. In addition, higher amounts of metal species were detected in the particles as the BDEs between the metal and carbon or oxygen increased.

Through this, it was verified that waste mulching LDPE adsorbs metal compounds derived from the soil due to its own physical properties and deterioration, and when incinerated, particulate pollutants including transition metals and other metals that contribute to overproduction of or reduction in ROS were released. In particular, $\mathrm{Cu}, \mathrm{Fe}$, and $\mathrm{Al}$ were identified as major metal components contained within the fine particulate matter. These metal species can cause human and biohazardous effects through the inhalation or adsorption of fine particulates.

However, in this study, waste mulching LDPE was limited to samples collected in a single area, and in order to satisfy the optimized $\mathrm{X}$-ray signal count, the acceleration voltage was set to $15 \mathrm{kV}$, and the minimum measurable particle range at x200 magnification under the condition corresponds to "particle diameter $\left(D_{p}\right)>1 \mu \mathrm{m}$ ", so in this study, particulate pollutants less than $1 \mu \mathrm{m}$ were excluded from the analysis. In addition, the experiment was mainly conducted using qualitative analysis, not quantitative analysis. In the future, 
these limitations should be supplemented through follow-up studies. In addition, further studies to quantify the harmfulness of particulate pollutants contained in metal compounds discharged from the incineration of waste mulching LDPE should be undertaken.

Author Contributions: Conceptualization, T.-H.K.; methodology, T.-H.K., M.-S.K., J.K.; software, B.-H.C.; validation, T.-H.K., C.-S.Y., Y.-K.K., M.-S.K.; formal analysis, T.-H.K.; investigation, B.-H.C.; resources, T.-H.K., B.-H.C.; data curation, T.-H.K., B.-H.C.; writing-original draft preparation, T.-H.K.; writing-review and editing, J.K.; visualization, T.-H.K., B.-H.C.; supervision, T.-H.K., J.K.; project administration, T.-H.K.; funding acquisition, T.-H.K. All authors have read and agreed to the published version of the manuscript.

Funding: This work was carried out with the support of "Cooperative Research Program for Agriculture Science and Technology Development (Project No. PJ014283022021)" Rural Development Administration, Korea, and Green Convergence Professional Manpower Training Program of the Korea Environmental Industry and Technology Institute funded by the Ministry of Environment.

Institutional Review Board Statement: Not applicable.

Informed Consent Statement: Not applicable.

Data Availability Statement: Not applicable.

Conflicts of Interest: The authors declare no conflict of interest.

\section{References}

1. Joint Related Ministries. The Second Implementation Plan for the Fine Dust Season Management System (Proposal); Joint Related Ministries: Jacksonville, FL, USA, 2020; pp. 528-529.

2. Merrington, A. 9-Recycling of Plastics. In Applied Plastics Engineering Handbook, 2nd ed; Kutz, M., Ed.; William Andrew Publishing: Norwich, NY, USA, 2017; pp. 167-189.

3. Andrady, A.L. Microplastics in the marine environment. Mar. Pollut. Bull. 2011, 62, 1596-1605. [CrossRef]

4. Pascall, M.A.; Zabik, M.E.; Zabik, M.J.; Hernandez, R.J. Uptake of Polychlorinated Biphenyls (PCBs) from an Aqueous Medium by Polyethylene, Polyvinyl Chloride, and Polystyrene Films. J. Agric. Food Chem. 2005, 53, 164-169. [CrossRef] [PubMed]

5. Holmes, L.A.; Turner, A.; Thompson, R.C. Interactions between trace metals and plastic production pellets under estuarine conditions. Mar. Chem. 2014, 167, 25-32. [CrossRef]

6. Canellas, C.G.L.; Carvalho, S.M.F.; Anjos, M.J.; Lopes, R.T. Determination of Cu/Zn and Fe in human serum of patients with sickle cell anemia using radiation synchrotron. Appl. Radiat. Isotopes 2012, 70, 1277-1280. [CrossRef] [PubMed]

7. Dunaief, J.L. Iron Induced Oxidative Damage As a Potential Factor in Age-Related Macular Degeneration: The Cogan Lecture. Investig. Ophthalmol. Vis. Sci. 2006, 47, 4660-4664. [CrossRef] [PubMed]

8. Erie, J.C.; Good, J.A.; Butz, J.A.; Pulido, J.S. Reduced Zinc and Copper in the Retinal Pigment Epithelium and Choroid in Age-related Macular Degeneration. Am. J. Ophthalmol. 2009, 147, 276-282.e1. [CrossRef] [PubMed]

9. Karlsson, H.L.; Nilsson, L.; Möller, L. Subway Particles Are More Genotoxic than Street Particles and Induce Oxidative Stress in Cultured Human Lung Cells. Chem. Res. Toxicol. 2005, 18, 19-23. [CrossRef]

10. Kelly, F.J.; Fussell, J.C. Size, source and chemical composition as determinants of toxicity attributable to ambient particulate matter. Atmos. Environ. 2012, 60, 504-526. [CrossRef]

11. Wadge, A.; Hutton, M. The cadmium and lead content of suspended particulate matter emitted from a U.K. refuse incinerator. Sci. Total Environ. 1987, 67, 91-95. [CrossRef]

12. Wei, Y.; Liu, G.; Fu, B.; Liu, Y.; Xue, X. The transformation and enrichment of $\mathrm{Cd}$ in fine particulate matter during coal combustion The key roles of Ti-bearing components. Fuel 2021, 292, 120285. [CrossRef]

13. Picuno, P.; Sica, C.; Laviano, R.; Dimitrijević, A.; Scarascia-Mugnozza, G. Experimental tests and technical characteristics of regenerated films from agricultural plastics. Polym. Degrad. Stab. 2012, 97, 1654-1661. [CrossRef]

14. Balart, M.J.; Hao, X.; Davis, C.L. Automated SEM/EDS Analysis for Assessment of Trace Cross-Contamination in 316L Stainless Steel Powders. Metall. Mater. Trans. A 2021, 53, 345-358. [CrossRef]

15. Pietranik, A.; Kierczak, J.; Tyszka, R.; Schulz, B. Understanding Heterogeneity of a Slag-Derived Weathered Material: The Role of Automated SEM-EDS Analyses. Minerals 2018, 8, 513. [CrossRef]

16. Bender, R.; Neimke, D.; Niewöhner, L.; Barth, M.; Ebert, M. Discrimination of SINTOX ${ }^{\circledR}$ GSR against environmental particles and its automated investigation by SEM/EDS. Forensic Chem. 2021, 24, 100338. [CrossRef]

17. ASTM International. Standard Practice for Gunshot Residue Analysis by Scanning Electron Microscopy/Energy Dispersive X-Ray Spectrometry; ASTM E1588-20; ASTM: West Conshohocken, PA, USA, 2020.

18. Miyauchi, H.; Kumihashi, M.; Shibayama, T. The contribution of trace elements from smokeless powder to post firing residues. J. Forensic Sci. 1997, 43, 90-96. [CrossRef]

19. Petruk, W. (Ed.) Applied Mineralogy in the Mining Industry; Elsevier Science: Amsterdam, The Netherlands, 2000. 
20. Schulz, B.; Merker, G.; Gutzmer, J. Automated SEM mineral liberation analysis (MLA) with generically labelled EDX spectra in the mineral processing of rare earth element ores. Minerals 2019, 9, 527. [CrossRef]

21. Šegvić, B.; Ugarković, M.; Süssenberger, A.; Mählmann, R.F.; Moscariello, A. Compositional Properties and Provenance of Hellenistic Pottery From the Necropolis of Issa with Evidences on the Cross-Adriatic and the Mediterranean-Scale Trade. Mediterr. Archaeol. Archaeom. 2016, 16, 23-52.

22. Haberlah, D.; Owen, M.; Botha, P.W.; Gottlieb, P. SEM-EDS-based protocol for subsurface drilling mineral identification and petrological classification. In Proceedings of the 10th International Congress for Applied Mineralogy (ICAM), Trondheim, Norway, 1-5 August 2011; Springer: Berlin/Heidelberg, Germany, 2012; pp. 265-273.

23. Ford, F.D.; Wercholaz, C.R.; Lee, A. Predicting Process Outcomes for Sudbury Platinum-Group Minerals Using Grade-Recovery Modeling from Mineral Liberation Analyzer (MLA) Data. Can. Mineral. 2011, 49, 1627-1642. [CrossRef]

24. Grammatikopoulos, T. Quantitative Characterization of the REE Minerals by QEMSCAN from the Nechalacho Heavy Rare Earth Deposit; SGS Minerals Services: Mobile, AL, USA, 2013.

25. Rollinson, G.K.; Andersen, J.C.Ø.; Stickland, R.J.; Boni, M.; Fairhurst, R. Characterisation of non-sulphide zinc deposits using QEMSCAN ${ }^{\circledR}$. Miner. Eng. 2011, 8, 778-787. [CrossRef]

26. MacDonald, M.; Adair, B.; Bradshaw, D.; Dunn, M.; Latti, D. Learnings From Five Years of On-Site Mla at Kennecott Utah Copper Corporation: (Myth Busters Through Quantitative Evidence ... ); Springer: Berlin/Heidelberg, Germany, 2012 ; pp. 419-426.

27. Anderson, K.F.E.; Wall, F.; Rollinson, G.K.; Moon, C.J. Quantitative mineralogical and chemical assessment of the Nkout iron ore deposit, Southern Cameroon. Ore Geol. Rev. 2014, 62, 25-39. [CrossRef]

28. Korea Environment Corporation. Survey on the Agricultural Wastes in the Korea Environment Corporation; Korea Environment Corporation: Incheon, Korea, 2020.

29. Kim, H.S. Survey on the Incineration of Agricultural Byproducts and Wastes in Rural Areas; Ministry of Agriculture, Food and Rural Affairs: Guelph, ON, Canada, 2020.

30. Rural Development Administration's Pesticide Safety Information System. Available online: http://psis.rda.go.kr/psis/agc/res/ agchmRegistStusLst.ps (accessed on 23 August 2021).

31. Ahn, J.H.; Song, I.H.; Kang, M.S. Correlation between Raw Materials and Chemical Contents of Livestock Compost. J. Korean Soc. Agric. Eng. 2013, 55, 37-45.

32. Galván Josa, V.; Castellano, G.; Bertolino, S.R. Quantification by SEM-EDS in uncoated non-conducting samples. Radiat. Phys. Chem. 2013, 88, 32-37. [CrossRef]

33. Schwoeble, A.J.; David, L. Exline Current Methods in Forensic Gunshot Residue Analysis, 1st ed.; CRC Press: Abingdon, UK, 2000.

34. Aloupi, E.; Karydas, A.G.; Paradellis, T. Pigment analysis of wall paintings and ceramics from Greece and Cyprus. The optimum use of $\mathrm{x}$-ray spectrometry on specific archaeological issues. X-Ray Spectrom 2018, 29, 18. [CrossRef]

35. Krüsemann, H. SEMs and forensic science. Probl. Forensic Sci. 2001, 47, 110-121.

36. Hortolà, P. SEM examination of human erythrocytes in uncoated bloodstains on stone: Use of conventional as environmental-like SEM in a soft biological tissue (and hard inorganic material). J. Microsc. 2005, 218, 94-103. [CrossRef]

37. Schleicher, L.S.; Miller, J.W.; Watkins-Kenney, S.C.; Carnes-McNaughton, L.F.; Wilde-Ramsing, M.U. Non-destructive chemical characterization of ceramic sherds from Shipwreck 31CR314 and Brunswick Town, North Carolina. J. Archaeol. Sci. 2008, 35, 2824-2838. [CrossRef]

38. Yadav, R.K.; Shanker, R. Backscattering of $8-28 \mathrm{keV}$ electrons from a thick Al, Ti, Ag and Pt targets. J. Electron Spectrosc. Relat. Phenom. 2006, 151, 71-77. [CrossRef]

39. EPA Method 5G. Determination of Particulate Matter Emissions from Wood Heaters (Dilution Tunnel Sampling Location); EPA Method 5G: Washington, DC, USA, 2017.

40. Kim, M.U. Emission Characteristics of Fine Particulate Matter and Analysis of Air Quality Impact from Biomass Burning. Ph.D. Thesis, Sejong University, Seoul, Korea, 2019.

41. Park, S.; Choi, S.; Park, G.; Kim, J.; Bong, C.; Park, S.; Kim, J.; Hwang, U. Collection Characteristics of Particulate Matters from Biomass Burning by Control Devices: Mainly Commercial Meat Cooking. J. Korean Soc. Atmos. Environ. 2011, 27, 641-649. [CrossRef]

42. Draxler, R. Ronald Hysplit_4 User's Guide; National Oceanic and Atmospheric Administration: Washington, DC, USA, 1999.

43. Akbari, M.Z.; Thepnuan, D.; Wiriya, W.; Janta, R.; Punsompong, P.; Hemwan, P.; Charoenpanyanet, A.; Chantara, S. Emission factors of metals bound with PM2.5 and ashes from biomass burning simulated in an open-system combustion chamber for estimation of open burning emissions. Atmos. Pollut. Res. 2021, 12, 13-24. [CrossRef]

44. Hosseini, S.; Shrivastava, M.; Qi, L.; Weise, D.R.; Cocker, D.R.; Miller, J.W.; Jung, H.S. Effect of low-density polyethylene on smoke emissions from burning of simulated debris piles. J. Air Waste Manage Assoc. 2014, 64, 690-703. [CrossRef] [PubMed]

45. Redondo-Bermúdez, M.d.C.; Gulenc, I.T.; Cameron, R.W.; Inkson, B.J. 'Green barriers' for air pollutant capture: Leaf micromorphology as a mechanism to explain plants capacity to capture particulate matter. Environ. Pollut. 2021, 288, 117809. [CrossRef]

46. Cholakian, A.; Coll, I.; Colette, A.; Beekmann, M. Exposure of the population of southern France to air pollutants in future climate case studies. Atmos. Environ. 2021, 264, 118689. [CrossRef]

47. Huang, Y.; Cheng, X. Chapter 22-Characteristics and sources of atmospheric particulate matter and health risk in Southwest China. In Asian Atmospheric Pollution; Singh, R.P., Ed.; Elsevier: Amsterdam, The Netherlands, 2022; pp. $409-433$. 
48. ISO. Particle Size Analysis_Image Analysis Methods; ISO 13322-1:2014; ISO: Geneva, Switzerland, 2014

49. Jillavenkatesa, A.; Lum, L.H.; Dapkunas, S. NIST Recommended Practice Guide: Particle Size Characterization; NIST: Gaithersburg, MD, USA, 2001.

50. Luo, Y.R. Comprehensive Handbook of Chemical Bond Energies; CRC Press: Boca Raton, FL, USA, 2007.

51. Shah, A.D.; Huffman, G.P.; Huggins, F.E.; Shah, N.; Helble, J.J. Behavior of carboxyl-bound potassium during combustion of an ion-exchanged lignite. Fuel Process. Technol. 1995, 44, 105-120. [CrossRef]

52. Chen, Y.; Shah, N.; Huggins, F.E.; Huffman, G.P.; Linak, W.P.; Miller, C.A. Investigation of primary fine particulate matter from coal combustion by computer-controlled scanning electron microscopy. Fuel Process. Technol. 2004, 85, 743-761. [CrossRef]

53. MAC-Micro-Analysis Consultants. Available online: https:/ / www.macstandards.co.uk (accessed on 12 January 2022).

54. Löndahl, J.; Massling, A.; Pagels, J.; Swietlicki, E.; Vaclavik, E.; Loft, S. Size-resolved respiratory-tract deposition of fine and ultrafine hydrophobic and hygroscopic aerosol particles during rest and exercise. Inhal. Toxicol. 2007, 19, 109-116. [CrossRef]

55. Löndahl, J.; Pagels, J.; Swietlicki, E.; Zhou, J.; Ketzel, M.; Massling, A.; Bohgard, M. A set-up for field studies of respiratory tract deposition of fine and ultrafine particles in humans. J. Aerosol Sci. 2006, 37, 1152-1163. [CrossRef]

56. Tseng, H.; Wey, M.; Fu, C. Carbon materials as catalyst supports for SO2 oxidation: Catalytic activity of CuO-AC. Carbon 2003, 41, 139-149. [CrossRef]

57. Tseng, H.; Wey, M. Study of SO2 adsorption and thermal regeneration over activated carbon-supported copper oxide catalysts. Carbon 2004, 42, 2269-2278. [CrossRef]

58. Jemec Kokalj, A.; Dolar, A.; Titova, J.; Visnapuu, M.; Škrlep, L.; Drobne, D.; Vija, H.; Kisand, V.; Heinlaan, M. Long Term Exposure to Virgin and Recycled LDPE Microplastics Induced Minor Effects in the Freshwater and Terrestrial Crustaceans Daphnia magna and Porcellio scaber. Polymers 2021, 13, 771. [CrossRef]

59. Thipse, S.S.; Schoenitz, M.; Dreizin, E.L. Morphology and composition of the fly ash particles produced in incineration of municipal solid waste. Fuel Process. Technol. 2002, 75, 173-184. [CrossRef]

60. Prideaux, E. Plastic incineration rise draws ire. Japan Times, 3 November 2007.

61. Chemical Information. Available online: http://msds.kosha.or.kr/MSDSInfo/kcic/english/msdssearch.do (accessed on 1 November 2021)

62. Chen, S.; Liu, Z.; Jiang, S.; Hou, H. Carbonization: A feasible route for reutilization of plastic wastes. Sci. Total Environ. 2020, 710, 136250. [CrossRef] [PubMed]

63. Alabi-Babalola, O.; Aransiola, E.; Shittu, T. Adsorption and Kinetic Study of Activated Carbon Produced from Post-Consumer Low-Density Polyethylene (LDPE) Wastes. Adv. Chem. Eng. Sci. 2021, 11, 38. [CrossRef]

64. Alimi, O.S.; Farner Budarz, J.; Hernandez, L.M.; Tufenkji, N. Microplastics and nanoplastics in aquatic environments: Aggregation, deposition, and enhanced contaminant transport. Environ. Sci. Technol. 2018, 52, 1704-1724. [CrossRef]

65. Teuten, E.L.; Saquing, J.M.; Knappe, D.R.; Barlaz, M.A.; Jonsson, S.; Björn, A.; Rowland, S.J.; Thompson, R.C.; Galloway, T.S.; Yamashita, R. Transport and release of chemicals from plastics to the environment and to wildlife. Philos. Trans. R. Soc. B Biol. Sci. 2009, 364, 2027-2045. [CrossRef]

66. Brennecke, D.; Duarte, B.; Paiva, F.; Caçador, I.; Canning-Clode, J. Microplastics as vector for heavy metal contamination from the marine environment. Estuar. Coast Shelf Sci. 2016, 178, 189-195. [CrossRef]

67. Werkenthin, M.; Kluge, B.; Wessolek, G. Metals in European roadside soils and soil solution-A review. Environ. Pollut. 2014, 189, 98-110. [CrossRef]

68. Baran, A.; Wieczorek, J.; Mazurek, R.; Urbański, K.; Klimkowicz-Pawlas, A. Potential ecological risk assessment and predicting zinc accumulation in soils. Environ. Geochem. Health 2018, 40, 435-450. [CrossRef]

69. Habtemariam, S. Modulation of Reactive Oxygen Species in Health and Disease. Antioxidants 2019, 8, 513. [CrossRef] 